\title{
Effect of Variety and Urea Super Granule on Growth and Yield of Wheat M. S. Islam ${ }^{1}$, A. U. Sarker ${ }^{2}$, M. A. Kader ${ }^{2}$, G. C. Biswas ${ }^{3}$ and M. M. Islam ${ }^{4}$ \\ ${ }^{1}$ Bangladesh Water Development Board, Dhaka \\ ${ }^{2}$ Dept. of Agronomy, Bangladesh Agricultural University, Mymenisngh-2202 \\ ${ }^{3}$ Dept. of Genetic Engg. and Biotech., SUST, Sylhet-3114 \\ ${ }^{4}$ Salimgang College, Bramanbaria
}

\begin{abstract}
The experiment was carried out at Agronomy Field Lab of Bangladesh Agricultural University (BAU), Mymensingh during the period from November 2009 to March 2010 with a view of finding out the effect of appropriate dose of USG on growth and yield of wheat. Three wheat varieties viz. Shatabdi, Bijoy and Prodip and 6 levels of nitrogen $\left(T_{0}, T_{1}, T_{2}, T_{3}, T_{4}\right.$ and $\left.T_{5}\right)$ were applied as treatments in this study. Among the application of USG on morpho-physiological and growth characters of wheat, the maximum plant height $(98.33 \mathrm{~cm})$, number of spikelet (21.33) and sterile spieklet (19.87) were found from $\mathrm{V}_{3} \mathrm{~T}_{5}$. Similarly, $\mathrm{V}_{2} \mathrm{~T}_{3}$ produced the highest no. of spikelet spile ${ }^{-1}(11.50)$ and grain yield $\left(2.75 \mathrm{t} \mathrm{ha}^{-1}\right)$ whereas similar treatment also showed the maximum no of non effective tiller (1.07) with $\mathrm{V}_{1} \mathrm{~T}_{3}$. The treatment combination of $\mathrm{V}_{2} \mathrm{~T}_{2}$ were recorded the highest on 1000-grain yield (51.98 g), no of non sterile spike (2.07) and no of grains spike ${ }^{-1}$ (48.87). The highest no of total tiller hill ${ }^{-1}$ (5.13) and effective tiller (4.33) were taken from the treatment combinations of $\mathrm{V}_{1} \mathrm{~T}_{5}$. The highest straw yield $\left(4.67\right.$ tha $\left.^{-1}\right)$ was recorded in $\mathrm{V}_{2} \mathrm{~T}_{4}$.
\end{abstract}

Key Words: Wheat varieties, Dose of USG, Morphophysiological and growth characters

\section{Introduction}

Wheat (Triticum aestivum L.) is one of the major cereal crops of the world ranking first both in acreage and production among the cereal crops. It provides more nourishment for the nation of the world than any other food crops. It supplies carbohydrate, protein, minerals and vitamin and is more preferable to rice for its higher seed protein content, about $12 \%$ protein, $1.72 \%$ fat, $69.60 \%$ carbohydrates and $27.20 \%$ mineral matter (BARI, 1997). In Bangladesh, wheat is the second important cereal crop next to rice. The area under wheat cultivation during 2007-2008 was about 5.59 lakh hectares producing 9.76 lakh tons of wheat grain with an average yield of 1.75 tons per hectare (BBS, 2008). Scarcity of food has become a chronic problem of this country and to mitigate the food shortages, measures should be taken to increase total food production. Appropriate cultivation techniques and doses of fertilizers are most important for better growth for any crops. Among the fertilizers, nitrogen plays a vital role in producing higher grain yield. Wheat yield increases with the increase of nitrogen fertilizer (Singh et al., 1986). Rate of $\mathrm{N}$ application has a great influence on growth, development and yield of wheat. Grain yield of wheat increases with increasing nitrogen level up to $120 \mathrm{~kg} \mathrm{ha}^{-1}$ (Malik, 1981). Prilled urea is a fast releasing nitrogen fertilizer which is usually broadcast in splits causes considerable loss of ammonia by volatilization, immobilization, denitrification and surface run off etc. On the other hand, deep placement of slow releasing nitrogenous fertilizer like urea supergranule (USG) reduces loss as well as increases its efficiency in dry land rabi crops. The present study was, therefore, undertaken to observe the performance of three modern wheat varieties under the effect of USG and optimum levels which will reduce the requirement of urea fertilizer.

\section{Materials and Methods}

The experiment was conducted at the Agronomy Field Laboratory, Bangladesh Agricultural University, Mymensingh, during the period from November 2009 to March 2010. The experimental field was a high land belonging to the Old Brahmaputra Floodplain Agro Ecological Zone (AEZ) (UNDP and FAO, 1988). The soil of the experimental field was sandy loam having $\mathrm{pH}$ 6.4. Three wheat varieties i.e. Shatabdi, Bijoy and Prodip were used as plant materials for this experiment under six level of nitrogen (USG) viz. control $\left(\mathrm{T}_{0}\right), 100 \%$ nitrogen of BARI recommended dose applied as prilled urea $\left(\mathrm{T}_{1}\right)$; $25 \%$ nitrogen of BARI recommended dose applied as USG $\left(\mathrm{T}_{2}\right), 50 \%$ nitrogen of BARI recommended dose applied as USG $\left(\mathrm{T}_{3}\right), 75 \%$ nitrogen of BARI recommended dose applied as USG $\left(\mathrm{T}_{4}\right)$ and $100 \%$ nitrogen of BARI recommended dose applied as USG $\left(T_{5}\right)$ on the growth and yield of wheat. Nitrogen were applied at the rate of BARI recommended dose as prilled urea $180 \mathrm{~kg} \mathrm{ha}^{-1}$ at the time of final land preparation and the urea super granule were applied as per treatment in each plot. Plant protection measures was not required, as the crop was free from insect and disease attack. The crop was harvested at full maturity. Grain and straw were then any in the sun for four days. The harvested crops were threshed plot-wise and grain and straw yields were recorded accordingly at $14 \%$ moisture basis and converted to $\mathrm{t}$ $\mathrm{ha}^{-1}$. The experiment was laid out in a randomized complete block design with three replications. Analysis of variance (ANOVA) was done with the help of computer package M-STATC. The mean 
differences among the treatments were adjusted with Duncan's Multiple Range Test (DMRT).

\section{Results and Discussion}

Results of the present study have been presented and discussed in this chapter. The summary of analysis of variance has been presented. Results are presented in Table 1 and Figures 1 to 3. Plant height did not vary significantly due to the combined effect of variety and USG levels (Fig. 1). The highest plant height (98.33 $\mathrm{cm}$ ) was observed in $\mathrm{V}_{3} \mathrm{~T}_{5}$ and the lowest plant height $(86.80 \mathrm{~cm})$ was observed in $\mathrm{V}_{1} \mathrm{~T}_{1}$ combination (Fig. $1)$.

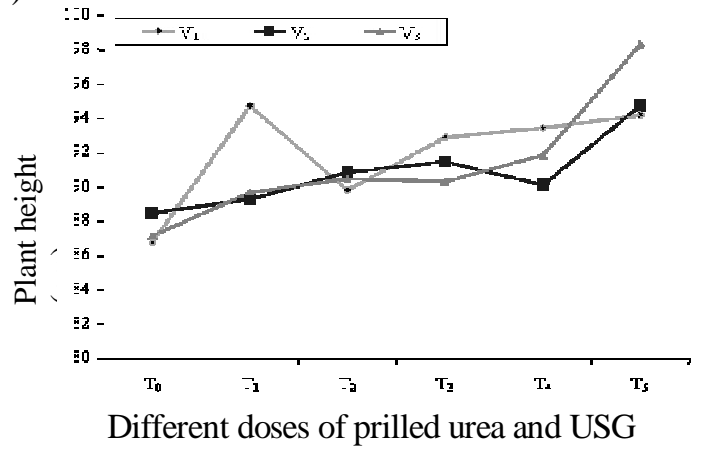

Note:

$\mathrm{V}_{1}=$ BARI 24 (Shatabdi); $\mathrm{V}_{2}=$ BARI 23 (Bijoy); $\mathrm{V}_{3}$ $=$ BARI 24 (Prodip)

$\mathrm{T}_{0}=$ Control (No nitrogen); $\mathrm{T}_{1}=100 \%$ nitrogen of BARI recommended dose applied as prilled urea

$\mathrm{T}_{2}=25 \%$ nitrogen of BARI recommended dose applied as USG; $\mathrm{T}_{3}=50 \%$ nitrogen of BARI recommended dose applied as USG.

$\mathrm{T}_{4}=75 \%$ nitrogen of BARI recommended dose applied as USG; $\mathrm{T}_{5}=100 \%$ nitrogen of BARI recommended dose applied as USG

\section{Figure 1. Interaction effect of variety, prilled urea} \& USG on plant height $(\mathrm{cm})$ of wheat

Number of total tillers hill ${ }^{-1}$ was significantly influenced by the combined effect of variety and USG levels (Table 1). The highest number of tillers hill ${ }^{-1}$ (5.13) was recorded in $\mathrm{V}_{1} \mathrm{~T}_{5}$, which was statistically similar to $\mathrm{V}_{2} \mathrm{~T}_{4}$ (4.87) and $\mathrm{V}_{3} \mathrm{~T}_{5}$ (4.87). The lowest number of tillers hill ${ }^{-1}$ was observed in $\mathrm{V}_{1} \mathrm{~T}_{0}$ (3.33) which was statistically similar to $\mathrm{V}_{1} \mathrm{~T}_{0}$ (3.33).

A non significant variation was found to be the effect of variety and USG on effective tillers hill ${ }^{-1}$ (Table 1). The highest effective tillers hill ${ }^{-1}$ (4.33) was recorded in $\mathrm{V}_{1} \mathrm{~T}_{5}$ followed by $\mathrm{V}_{3} \mathrm{~T}_{5}$ (4.20) and the lowest effective tillers hill ${ }^{-1}$ (2.53) was recorded in $\mathrm{V}_{3} \mathrm{~T}_{0}$. Urea supergranule application methods encouraged effective tillers production with variety and for that the effective tiller increased with the increase of USG treatments.
Non effective tillers hill ${ }^{-1}$ did not vary remarkably due to the combination variety and USG application levels (Table 1). The maximum number of non effective tillers hill-1 ${ }^{-1}$ (1.07) was found with the both $\mathrm{V}_{1} \mathrm{~T}_{3}$ and $\mathrm{V}_{2} \mathrm{~T}_{3}$. On the other hand, the lowest $(0.47)$ was recorded in $\mathrm{V}_{3} \mathrm{~T}_{2}$ (Table 1).

Number of total spilkelets was found significant variation among the effect of varieties and USG treatments (Table 1). The highest spikelet (21.33) was found $\mathrm{V}_{3} \mathrm{~T}_{5}$, which was statistically more or less similar to V2T4 (21.00). Similarly, the lowest spikelet (17.13) was recorded in $\mathrm{V}_{1} \mathrm{~T}_{0}$.

Number of spikelets spike $^{-1}$ was significantly influenced by the effect of variety and USG treatments level (Fig. 2). The highest number of spikelets spike ${ }^{-1}(11.50)$ was found from the treatment combinations of $\mathrm{V}_{2} \mathrm{~T}_{3}$. However, the lowest number of spikelets spike ${ }^{-1}$ (8.78) was given by the treatment combinations of $\mathrm{V}_{1} \mathrm{~T}_{0}$ (Fig. 2).

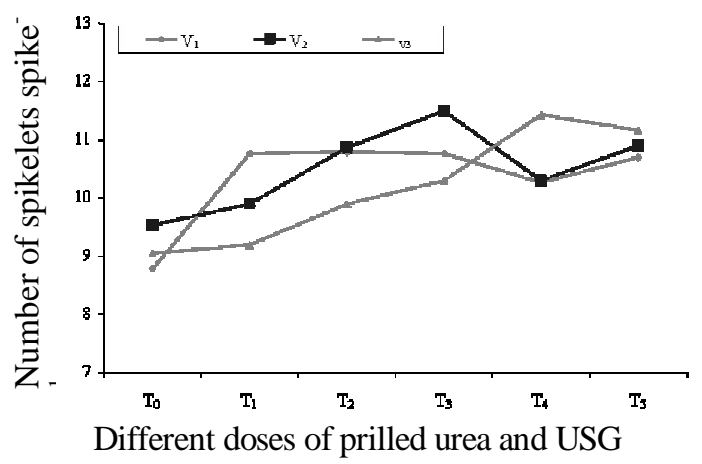

Figure 2. Combined effect of variety, prilled urea \& USG on number of spikelets/spike of wheat

Number of sterile spikelets spike ${ }^{-1}$ was significant to be the effect of variety and different levels of USG (Table 1). The highest number of sterile spikelets spike ${ }^{-1}$ (19.87) was obtained from $\mathrm{V}_{3} \mathrm{~T}_{5}$ and the lowest number of sterile spikelets spike $^{-1}$ (15.60) was observed in $\mathrm{V}_{1} \mathrm{~T}_{0}$.

A significant variation was found on the effect of varieties and different treatments of USG (Table 1). The maximum non sterile spikeletes spike ${ }^{-1}$ (2.07) was found from the combinations of $\mathrm{V}_{2} \mathrm{~T}_{2}$ and the lowest non sterile spikeletes spike $^{-1}$ (1.20) was recorded with the both combinations of variety and USG treatment viz. $\mathrm{V}_{1} \mathrm{~T}_{4}$ and $\mathrm{V}_{3} \mathrm{~T}_{0}$.

Number of grains spike ${ }^{-1}$ of wheat varied significantly due to combined effect of variety and USG levels (Table 1). The highest number of grains spike $^{-1}$ 
(50.13) was found in $\mathrm{V}_{3} \mathrm{~T}_{5}$ and the lowest number of grains spike ${ }^{-1}$ (32.20) was obtained in $\mathrm{V}_{3} \mathrm{~T}_{1}$.

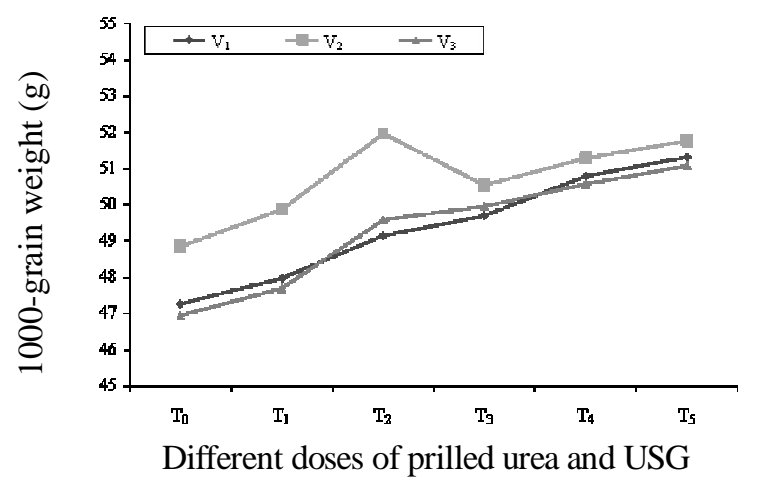

Grain yield did not vary significant due to the effect between variety and USG levels (Table 1). The

Figure 3. Combined effect of variety, prilled urea \& USG on 1000-grain weight (g) of wheat highest grin yield $\left(2.75 \mathrm{t} \mathrm{ha}^{-1}\right)$ was recorded in $\mathrm{V}_{1} \mathrm{~T}_{3}$ and the lowest grain yield was recorded from $\mathrm{V}_{2} \mathrm{~T}_{0}$ $\left(1.00 \mathrm{tha}^{-1}\right)$.

The combined effect of variety and USG levels did not vary significant on weight of 1000- grains (g) (Fig. $3)$. The highest 1000 -grains weight $(51.98 \mathrm{~g})$ was observed in $\mathrm{V}_{2} \mathrm{~T}_{2}$ and the lowest 1000-grains weight (46.96 g) was recorded in $\mathrm{V}_{3} \mathrm{~T}_{0}$ (Fig. 3).

A non significant variation was found between the variety and USG levels on straw yield where the maximum straw yield $\left(4.67 \mathrm{t} \mathrm{ha}^{-1}\right)$ was obtained from $\mathrm{V}_{2} \mathrm{~T}_{4}$, which was statistically identical with $\mathrm{V}_{2} \mathrm{~T}_{5}$ (4.25 t ha ${ }^{-1}$ ) and $\mathrm{V}_{2} \mathrm{~T}_{3}$ (4.25). In contrast, the lowest straw yield $\left(2.17 \mathrm{t} \mathrm{ha}^{-1}\right)$ was obtained in $\mathrm{V}_{2} \mathrm{~T}_{0}$.

Table 1. Interaction effect of variety and urea super granule on growth and yield of wheat

\begin{tabular}{|c|c|c|c|c|c|c|c|c|c|}
\hline $\begin{array}{c}\text { Treatment } \\
\text { s }\end{array}$ & $\begin{array}{c}\text { No. of } \\
\text { total } \\
\text { tillers } \\
\text { hill }^{-1}\end{array}$ & $\begin{array}{c}\text { No. of } \\
\text { effective } \\
\text { tillers } \\
\text { hill }^{-1}\end{array}$ & $\begin{array}{l}\text { No. of non- } \\
\text { effective } \\
\text { tillers hill }^{-1}\end{array}$ & $\begin{array}{c}\text { No. of total } \\
\text { spikelet }\end{array}$ & $\begin{array}{c}\text { Sterile } \\
\text { spikelet }\end{array}$ & $\begin{array}{c}\text { Non } \\
\text { sterile } \\
\text { spikelet }\end{array}$ & $\begin{array}{l}\text { No. of } \\
\text { grains } \\
\text { spike }^{-1}\end{array}$ & $\begin{array}{c}\text { Grain } \\
\text { yield } \\
\left(\mathrm{t} \mathrm{ha}^{-1}\right)\end{array}$ & $\begin{array}{c}\text { Straw } \\
\text { yield } \\
\left(\mathrm{t} \mathrm{ha}^{-1}\right)\end{array}$ \\
\hline $\mathrm{V}_{1} \times \mathrm{T}_{0}$ & $3.33 \mathrm{~h}$ & $2.53 \mathrm{~h}$ & $0.80 \mathrm{abc}$ & $17.13 \mathrm{~h}$ & $15.60 \mathrm{~h}$ & $1.53 \mathrm{ab}$ & $32.13 \mathrm{gh}$ & $1.33 \mathrm{gi}$ & $2.83 \mathrm{~cd}$ \\
\hline $\mathrm{V}_{1} \times \mathrm{T}_{1}$ & 4.20 cde & $3.67 \mathrm{bc}$ & $0.53 \mathrm{bc}$ & 19.93 bcde & $18.40 \mathrm{bcd}$ & $1.53 \mathrm{ab}$ & $39.20 \mathrm{de}$ & $\begin{array}{l}1.58 \\
\text { fghi }\end{array}$ & $3.17 \mathrm{bcd}$ \\
\hline $\mathrm{V}_{1} \times \mathrm{T}_{2}$ & $\begin{array}{l}3.93 \\
\text { defg }\end{array}$ & $3.53 \mathrm{bcd}$ & $0.60 \mathrm{abc}$ & $20.40 \mathrm{abc}$ & $18.67 \mathrm{bc}$ & $1.73 \mathrm{ab}$ & $41.87 \mathrm{~cd}$ & $\begin{array}{c}1.92 \\
\text { defgh }\end{array}$ & $3.75 \mathrm{abc}$ \\
\hline $\mathrm{V}_{1} \times \mathrm{T}_{3}$ & $4.80 \mathrm{ab}$ & $3.67 \mathrm{bc}$ & $1.07 \mathrm{a}$ & 20.00 bcde & $18.33 \mathrm{bcd}$ & $1.67 \mathrm{ab}$ & $44.20 \mathrm{bc}$ & $2.75 \mathrm{a}$ & $3.92 \mathrm{abc}$ \\
\hline $\mathrm{V}_{1} \times \mathrm{T}_{4}$ & $4.80 \mathrm{ab}$ & $3.87 \mathrm{ab}$ & $0.93 \mathrm{abc}$ & $18.93 \mathrm{efg}$ & 17.73 bcde & $1.20 \mathrm{bc}$ & $43.60 \mathrm{c}$ & $\begin{array}{l}2.50 \\
\text { abcd }\end{array}$ & $3.67 \mathrm{abc}$ \\
\hline $\mathrm{V}_{1} \times \mathrm{T}_{5}$ & $5.13 \mathrm{a}$ & $4.33 \mathrm{a}$ & $0.80 \mathrm{abc}$ & $20.20 \mathrm{abcd}$ & $18.56 \mathrm{bc}$ & $1.40 \mathrm{ab}$ & $47.27 \mathrm{ab}$ & $\begin{array}{l}2.58 \\
a b c\end{array}$ & $4.08 a b c$ \\
\hline $\mathrm{V}_{2} \times \mathrm{T}_{0}$ & $3.53 \mathrm{gh}$ & $2.87 \mathrm{fg}$ & $0.67 \mathrm{abc}$ & $17.60 \mathrm{~h}$ & $1567 k$ & $1.93 \mathrm{a}$ & $31.80 \mathrm{~h}$ & $1.00 \mathrm{i}$ & $2.17 \mathrm{~d}$ \\
\hline $\mathrm{V}_{2} \times \mathrm{T}_{1}$ & $3.47 \mathrm{gh}$ & $\begin{array}{l}3.00 \\
\text { defg }\end{array}$ & $0.53 \mathrm{bc}$ & $17.93 \mathrm{gh}$ & 16.67 efgh & $1.40 \mathrm{ab}$ & $\begin{array}{l}35.40 \\
\text { fgh }\end{array}$ & $\begin{array}{c}1.92 \\
\text { defgh }\end{array}$ & $3.08 \mathrm{bcd}$ \\
\hline $\mathrm{V}_{2} \times \mathrm{T}_{2}$ & $3.40 \mathrm{~h}$ & $3.00 \mathrm{efg}$ & $0.53 \mathrm{bc}$ & $21.00 \mathrm{ab}$ & $18.93 \mathrm{ab}$ & $2.07 \mathrm{a}$ & $48.87 \mathrm{a}$ & $\begin{array}{l}2.08 \\
\text { cdef }\end{array}$ & $3.92 \mathrm{abc}$ \\
\hline $\mathrm{V}_{2} \times \mathrm{T}_{3}$ & $4.53 \mathrm{bc}$ & $\begin{array}{l}3.47 \\
\text { bcde }\end{array}$ & $1.07 \mathrm{a}$ & $18.20 \mathrm{fgh}$ & $17.53 \mathrm{cdef}$ & $0.67 \mathrm{c}$ & $39.73 \mathrm{de}$ & $\begin{array}{c}1.92 \\
\text { defgh }\end{array}$ & $4.25 \mathrm{ab}$ \\
\hline $\mathrm{V}_{2} \times \mathrm{T}_{4}$ & $4.40 \mathrm{bcd}$ & $3.67 \mathrm{bc}$ & $0.73 \mathrm{abc}$ & 1740 & 1600 & 140 & $37.93 \mathrm{ef}$ & $2.67 \mathrm{ab}$ & $4.67 \mathrm{a}$ \\
\hline $\mathrm{V}_{2} \times \mathrm{T}_{5}$ & $4.87 \mathrm{ab}$ & $3.87 \mathrm{ab}$ & $1.00 \mathrm{ab}$ & $19.13 \mathrm{def}$ & $17.67 \mathrm{cde}$ & $1.53 \mathrm{ab}$ & $\begin{array}{l}41.40 \\
\text { cde }\end{array}$ & $\begin{array}{c}2.25 \\
\text { abcde }\end{array}$ & $4.25 \mathrm{ab}$ \\
\hline $\mathrm{V}_{3} \times \mathrm{T}_{0}$ & $3.33 \mathrm{~h}$ & $2.53 \mathrm{~g}$ & $0.80 \mathrm{abc}$ & $17.53 \mathrm{~h}$ & $16.27 \mathrm{gh}$ & $1.20 \mathrm{bc}$ & $32.80 \mathrm{gh}$ & $\begin{array}{c}1.42 \\
\text { ghi }\end{array}$ & $3.08 \mathrm{bcd}$ \\
\hline $\mathrm{V}_{3} \times \mathrm{T}_{1}$ & $3.67 \mathrm{fgh}$ & $\begin{array}{l}3.13 \\
\text { cdef }\end{array}$ & $0.53 \mathrm{bc}$ & $17.93 \mathrm{gh}$ & $16.47 \mathrm{fgh}$ & $1.47 \mathrm{ab}$ & $32.20 \mathrm{gh}$ & $\begin{array}{l}1.50 \\
\text { fghi }\end{array}$ & $3.17 \mathrm{bcd}$ \\
\hline $\mathrm{V}_{3} \times \mathrm{T}_{2}$ & $\begin{array}{l}3.73 \\
\text { efgh }\end{array}$ & $\begin{array}{l}3.27 \\
\text { cdef }\end{array}$ & $0.47 \mathrm{c}$ & 18.87 efg & $17.20 \mathrm{defg}$ & $1.67 \mathrm{ab}$ & $35.67 \mathrm{fg}$ & $\begin{array}{l}1.50 \\
\text { fghi }\end{array}$ & $3.00 \mathrm{bcd}$ \\
\hline $\mathrm{V}_{3} \times \mathrm{T}_{3}$ & 4.07 cde & 3.20 & $0.87 \mathrm{abc}$ & $19.53 \mathrm{cde}$ & $18.00 \mathrm{bcd}$ & $1.53 \mathrm{ab}$ & $43.40 \mathrm{c}$ & 1.83 & 3.50 \\
\hline
\end{tabular}




\begin{tabular}{|c|c|c|c|c|c|c|c|c|c|}
\hline & cdef & & & & & & efgh & abcd \\
\hline $\mathrm{V}_{3} \times \mathrm{T}_{4}$ & $\begin{array}{c}4.20 \\
\mathrm{cdef}\end{array}$ & $\begin{array}{c}3.40 \\
\mathrm{bcde}\end{array}$ & $0.87 \mathrm{abc}$ & $19.73 \mathrm{cde}$ & $18.27 \mathrm{bcd}$ & $1.47 \mathrm{ab}$ & $49.47 \mathrm{a}$ & $\begin{array}{c}2.08 \\
\mathrm{bcdef}\end{array}$ & $3.75 \mathrm{abc}$ \\
\hline $\mathrm{V}_{3} \times \mathrm{T}_{5}$ & $4.87 \mathrm{ab}$ & $4.20 \mathrm{a}$ & $0.67 \mathrm{abc}$ & $21.33 \mathrm{a}$ & $19.87 \mathrm{a}$ & $1.40 \mathrm{ab}$ & $50.13 \mathrm{a}$ & $\begin{array}{c}2.00 \\
\mathrm{cdef}\end{array}$ & $3.83 \mathrm{abc}$ \\
\hline $\mathbf{C V}(\boldsymbol{\%})$ & $\mathbf{6 . 3 9}$ & $\mathbf{8 . 2 3}$ & $\mathbf{3 3 . 9 5}$ & $\mathbf{3 . 3 7}$ & $\mathbf{3 . 6 1}$ & $\mathbf{2 3 . 2 5}$ & $\mathbf{4 . 9 9}$ & $\mathbf{1 9 . 4 8}$ & $\mathbf{1 9 . 1 4}$ \\
\hline $\begin{array}{c}\text { LSD } \\
(\mathbf{0 . 0 5})\end{array}$ & $\mathbf{0 . 4 3 5 9}$ & $\mathbf{0 . 4 6 3 4}$ & $\mathbf{0 . 4 2 3 0}$ & $\mathbf{1 . 0 6 4}$ & $\mathbf{1 . 0 5 1}$ & $\mathbf{0 . 5 7 4 8}$ & $\mathbf{3 . 2 4 7}$ & $\begin{array}{c}\mathbf{0 . 0 5 2 4} \\
\mathbf{7}\end{array}$ & $\mathbf{0 . 1 1 7 3}$ \\
\hline $\begin{array}{c}\text { Levels of } \\
\text { sig }\end{array}$ & $\mathbf{n s}$ & $\mathbf{n s}$ & $\mathbf{n s}$ & $* *$ & $* *$ & $*$ & $* *$ & $\mathbf{n s}$ & $\mathbf{n s}$ \\
\hline
\end{tabular}

$*$ : Significant at $\mathrm{p} \leq 0.05$. **: Significant at $\mathrm{p} \leq 0.01$. NS: Not significant

\section{Conclusion}

From the above experiment, it can be mentioned that Bijoy showed better performance for the growth of wheat with $100 \%$ nitrogen of BARI recommended dose applied as USG. However, Shatabdi and Bijoy showed the best performance with same treatments. For the present study, it may be concluded that the higher seed yield of wheat could be obtained by using the variety Shatabdi $\left(\mathrm{V}_{1}\right)$ with $50 \%$ USG. However, further trails are necessary at different agroecological zones of the country to confirm this result.

\section{References}

BARI (Bangladesh Agricultural Research Institute). 1997. Increase wheat cultivation and decrease irrigation cost (A folder in Bengali), Wheat Res. Centre, Bangladesh Agril. Res. Inst., Nashipur, Dinajpur. pp.12-15.
BBS (Bangladesh Bureau of Statistics). 2008. Statistical Year Book of Bangladesh, Bangladesh Bur. Stat. Div. Min. Plan., Govt. Peoples Repub. Bangladesh, 144p.

Malik, C. V. S. 1981. Response of wheat varieties to different levels of nitrogen. Indian J. Agron., 26(1): 93-94.

Singh, G.; Singh, R. and Purashhttam, K. 1986. Response of wheat (Triticum aestivum) to nitrogen, phosphorus and potassium fertilization. Indian J. Agron., 41(1):157-159.

UNDP and FAO. 1988. Land Resources Appraisal of Bangladesh for Agricultural Development, Report 2, Agroecological Regions of Bangladesh. United Nations Development Programme and Food and Agriculture Organization. pp.212-221. 